\title{
Haemagglutinating activity, serum sensitivity and enterotoxigenicity of Aeromonas spp.
}

\author{
D. V. SINGH and S. C. SANYAL* \\ Department of Microbiology, Institute of Medical Sciences, Banaras Hindu University, Varanasi 221 005, India
}

\begin{abstract}
Summary. Of 97 isolates of Aeromonas spp. that were examined for haemagglutination (HA) and enterotoxigenicity, 35 were from clinical and 62 from environmental sources; 66 of them were also screened for sensitivity to normal human serum (NHS). HA was caused by 44 isolates $(45 \%)$; it was unrelated to the source of the strain, but it was caused by a higher proportion of the isolates of $A$. hydrophila than of $A$. sobria or $A$. caviae. Of the haemagglutinating strains, $82 \%$ were enterotoxigenic, whereas most of the non-haemagglutinating strains were non-toxigenic when tested initially. All the latter became enterotoxin producers after serial passage through rabbit ileal loops, but without change in HA. Most $(64 \%)$ of the isolates, including $68 \%$ of $A$. caviae $(72 \%$ of clinical and $65 \%$ of environmental), were resistant to the bactericidal action of NHS. Most (92\%) of the serumsensitive strains were killed by activation of both the classical and alternate pathways of complement, the others only by the alternate pathway. Most $(74 \%)$ of the serum-resistant strains caused fluid accumulation in the initial tests in ileal loops, regardless of species or source. Haemagglutinating and serum-resistant strains caused significantly more accumulation of fluid $(\mathrm{p}<0.05)$ than non-haemagglutinating and serum-sensitive strains. This study shows partial correlation between HA or serum sensitivity and enterotoxigenicity, but the properties are probably not genetically linked.
\end{abstract}

\section{Introduction}

Aeromonas spp. have been implicated in extraintestinal infections and diarrhoea in man, ${ }^{1,2}$ the strains often originating from water. A. hydrophila and $A$. sobria, but rarely $A$. caviae isolates, produced enterotoxin $^{3-6}$ and also showed resistance to the bactericidal action of normal human serum (NHS), ${ }^{7,8}$ Moreover, enterotoxigenic diarrhoeal isolates of $A$. hydrophila showed haemagglutination (HA) which was not sensitive to mannose and fucose; but Aeromonas strains showing HA sensitive to mannose and fucose, or no haemagglutination (NHA) were nontoxigenic strains of $A$. caviae, commonly from nondiarrhoeal infection or the environment. ${ }^{9}$

In this study, we have explored the HA and serumsensitivity patterns of clinical and environmental isolates of Aeromonas spp. and their correlations with enterotoxin production, species and source.

\section{Materials and methods}

\section{Bacterial strains}

Strains of Aeromonas from cases of acute diarrhoea in children and adults (35) and from environmental

Received 14 Jan. 1992; revised version accepted 28 May 1992. * Correspondence should be sent to Professor S. C. Sanyal. sources (62) were tested for HA and enterotoxin production (table I). Twenty-nine clinical and 37 environmental strains were also examined for susceptibility to NHS (table II). By the criteria of Popoff, ${ }^{10}$ strains were classified into three species ( $A$. hydrophila, $A$. sobria, A. caviae), according to their ability to hydrolyse aesculin, to ferment salicin, and to produce gas, acetoin and $\mathrm{H}_{2} \mathrm{~S}$. The strains were maintained in peptone agar stab cultures at room temperature and did not undergo more than three subcultures before being tested.

\section{Haemagglutination}

The method of Atkinson and Trust was used. ${ }^{11}$ Human group $\mathrm{O}$ erythrocytes were collected by venepuncture and stored in Alsever's solution at $4^{\circ} \mathrm{C}$. Before use, they were washed three times in phosphatebuffered saline (PBS; 0.04M, pH 7.4) and then a $3 \%$ suspension was prepared in PBS.

Colonies of overnight cultures of Aeromonas strains on nutrient agar plates were incubated in Brain Heart Infusion Broth (BHIB, Difco), and incubated for $18 \mathrm{~h}$ at $37^{\circ} \mathrm{C}$ to yield c. $10^{9}$ bacteria $/ \mathrm{ml}$. These cultures were centrifuged and washed twice in PBS.

HA tests were performed at room temperature by mixing $20 \mu \mathrm{l}$ of erythrocyte suspension with $20 \mu \mathrm{l}$ of bacterial suspension on a slide alongside a control suspension of erythrocytes and PBS, and gently 
Table I. Haemagglutinating activity and enterotoxigenicity of Aeromonas isolates

\begin{tabular}{|c|c|c|c|c|c|c|c|c|c|c|c|}
\hline \multirow{3}{*}{$\begin{array}{l}\text { Source and } \\
\text { species } \\
\text { of isolate }\end{array}$} & \multirow{3}{*}{$\begin{array}{l}\text { Number of } \\
\text { srains } \\
\text { tested }\end{array}$} & \multicolumn{8}{|c|}{ HA-positive strains } & \multicolumn{2}{|c|}{ NHA strains } \\
\hline & & \multirow[b]{2}{*}{ MS } & \multirow[b]{2}{*}{$\mathrm{MiS}$} & \multicolumn{5}{|c|}{ Number of strains showing } & \multirow{2}{*}{$\begin{array}{l}\text { Mean (SD) } \\
\text { volume of } \\
\text { fluid in } \\
\text { initial tests } \\
(\mathrm{ml} / \mathrm{cm} \text { of } \\
\text { RIL) }\end{array}$} & \multirow{2}{*}{$\begin{array}{c}\text { Number } \\
\text { of } \\
\text { strains }\end{array}$} & \multirow{2}{*}{$\begin{array}{l}\text { Mean (SD) } \\
\text { volume of } \\
\text { fluid in } \\
\text { initial tests } \\
(\mathrm{m} / / \mathrm{cm} \text { of } \\
\text { RIL) }\end{array}$} \\
\hline & & & & MFGS & MGS & FGS & MFGR & Any $\mathrm{HA}$ & & & \\
\hline \multicolumn{12}{|l|}{ Clinical } \\
\hline A. Midrophilu & 5 & $1(1)$ & $2(2)$ & & $1(0)$ & & & $4(3)$ & $0.71(0.05)$ & $1(0)$ & \\
\hline A whria & 15 & $3(3)$ & & $2(2)$ & & & & $5(5)$ & $0.69(0.11)$ & $10(2)$ & $0.43(0.03)$ \\
\hline A. arime & 15 & $5(4)$ & & & & l(1) & & $6(5)$ & $0.60(0.08)$ & $9(2)$ & $0.41(0.01)$ \\
\hline \multicolumn{12}{|l|}{ Enviromential } \\
\hline A. Hodrophita & 9 & & $3(2)$ & $2(2)$ & $2(0)$ & & & $7(4)$ & $1 \cdot 17(0 \cdot 44)$ & $2(0)$ & \\
\hline A. whriu & 16 & $5(5)$ & (11) & $2(2)$ & & & & $8(8)$ & $0.79(0.15)$ & $8(2)$ & $0.46(0.02)$ \\
\hline A. curke & 37 & $2(2)$ & $5(4)$ & $5(4)$ & $1(0)$ & & $1(1)$ & $14(11)$ & $0.61(0.09)$ & $23(10)$ & $0.48(0.04)$ \\
\hline Posituve control* & & & & & & & & & $1.20(0.20)$ & & \\
\hline Vegative controlt & & & & & & & & & $0.00(0.00)$ & & \\
\hline Tolit & 47 & $16(15)$ & $11(9)$ & $11(10)$ & $4(0)$ & $1(1)$ & $1(1)$ & $44(36)$ & & $53(16)$ & \\
\hline
\end{tabular}

Figures in parenthesis indicate number of enterotoxigenic strains in the initial tests before passage in RILs.

* BHIB culture of 1 . cholerate strain $569 \mathrm{~B}$.

$\div \mathrm{BHIB}$.

rocking by hand. Strains were considered HA-negative if agglutination did not occur within 5 min."

Sensitivity of $H A$ to sugars was studied in a similar three-volume test with $20 \mu$ of erythrocyte suspension $3 \% .20 \mu \mathrm{l}$ of sugar $1 \%$ in PBS. and $20 \mu \mathrm{l}$ of bacterial suspension. Reactions in the presence of $D$-mannose (M). L-fucose (F) or D-galactose $(G)$ were compared with a positive control (erythrocytes. bacteria and PBS) and a negative control ( $20 \mu$ lof erythrocytes and $40 \mu 1$ of PBS). The reaction was recorded as sensitive (S). if a previously positive result became negative in the presence of sugar, and resistant $(R)$ if it remained positive.

\section{Suscemibility to NHS}

Group $\mathrm{O}$ blood was obtained by venepuncture from healthy individuals with no history of aeromonas infection: pooled sera were separated and used immediately or stored at $-70^{\circ} \mathrm{C}$. Fresh or freshly thawed NHS was used unaltered or after addition of $10 \mathrm{~mm}$ $\mathrm{MgCl}_{2}$, ethylene glycol tetra-acetic acid (MgEGTA). prepared by the method of Fine et al.. ${ }^{12}$ giving a final concentration of $10 \mathrm{~mm}$ MgEGTA. Serum-sensitive Escherichia coli strain $\mathrm{K} 12$ served as a control for each experiment

Bactericidal actirity and complement activity were determined by the method of Carruthers and Kabat. ${ }^{13}$ Briefly. the bacterial inoculum (c. $10^{\circ} \mathrm{cfu}$ ) in $0.3 \mathrm{ml}$ of PBS was mixed with $0.7 \mathrm{ml}$ of NHS with and without MgEGTA: $0.1 \mathrm{ml}$ of the mixture was withdrawn for an initial viable count, and the remainder was incubated at $37^{\circ} \mathrm{C}$ for 30.60 and $120 \mathrm{~min}$. Serial 10 -fold dilutions in PBS were inoculated in duplicate on to nutrient agar plates and incubated overnight at $37^{\circ} \mathrm{C}$; bacterial colonies were then counted. Strains showing
$<10 \%$ survival (i.e., $>1 \log _{10}$ reduction in cfu) at 60 and $120 \mathrm{~min}$ were designated as showing prompt and delayed serum-sensitivity, respectively.

\section{Enterotoxin assay}

Live cells and culture filtrates of all the Aeromonas strains were tested for enterotoxigenicity in the adult rabbit ileal loop (RIL) model of De and Chatterjee ${ }^{14}$ as adopted by Annapurna and Sanyal. ${ }^{3}$ Those strains that caused little or no accumulation of fluid in the initial tests were subjected to successive passage through RILs until they caused fluid accumulation similar to that of the positive control strain 569B of Vibrio cholerae. ${ }^{15}$

\section{Results}

Of the 97 isolates of Aeromonas spp., $44(45 \%)$ were HA-positive (table I); these included $79 \%$ of the $A$. hydrophila, $42 \%$ of the $A$. sobria and $38 \%$ of the $A$. cariae isolates. The haemagglutinating strains of $A$. hydrophila and $A$. caviae were almost equally distributed between clinical and environmental sources, but there were proportionately more environmental strains of $A$. sobria, although the difference was not significant.

In the initial tests in RILs, live cells and culture filtrates of the majority $(82 \%)$ of the haemagglutinating strains caused fluid accumulation; these included $64 \%$ of the $A$. hydrophila, $100 \%$ of the $A$. sobria and $80 \%$ of the $A$. caviae strains. Most of these enterotoxigenic isolates showed MS-HA, MFS-HA or MFGS-HA. Although $30 \%$ of the non-haemagglutinating strains also showed a secretory response, the haemagglutinating strains caused significantly 
Table II. Serum-sensitivity and enterotoxigenicity of Aeromonas isolates

\begin{tabular}{|c|c|c|c|c|c|c|c|}
\hline \multirow{3}{*}{$\begin{array}{l}\text { Source and } \\
\text { species } \\
\text { of isolate }\end{array}$} & \multirow{3}{*}{$\begin{array}{l}\text { Number of } \\
\text { strains } \\
\text { tested }\end{array}$} & \multicolumn{4}{|c|}{ Serum-sensitive strains } & \multicolumn{2}{|c|}{ Serum-resistant strains } \\
\hline & & \multicolumn{2}{|c|}{$\begin{array}{l}\text { Number of strains in which } \\
\text { sensitivity was }\end{array}$} & \multirow{2}{*}{$\begin{array}{c}\text { Total } \\
\text { number } \\
\text { of strains }\end{array}$} & \multirow{2}{*}{$\begin{array}{c}\text { Mean (SD) } \\
\text { volume of fluid } \\
\text { in initial tests } \\
(\mathrm{ml} / \mathrm{cm} \text { of } \mathrm{RIL})\end{array}$} & \multirow{2}{*}{$\begin{array}{c}\text { Number } \\
\text { of } \\
\text { strains }\end{array}$} & \multirow{2}{*}{$\begin{array}{l}\text { Mean (SD) } \\
\text { volume of fluid } \\
\text { in initial tests } \\
(\mathrm{ml} / \mathrm{cm} \text { of } \mathrm{RIL})\end{array}$} \\
\hline & & prompt & delayed & & & & \\
\hline \multicolumn{8}{|l|}{ Clinical } \\
\hline A. hydrophila & 5 & $2(0)$ & & $2(0)$ & & $3(3)$ & $0.71(0.05)$ \\
\hline A. sobria & 10 & $3(1)$ & $2(1)$ & $5(2)$ & $0.50(0.01)$ & $5(5)$ & $0.72(0.13)$ \\
\hline A. caviae & 14 & $4(2)$ & & $4(2)$ & $0.45(0.05)$ & $10(6)$ & $0.65(0.11)$ \\
\hline \multicolumn{8}{|l|}{ Environmental } \\
\hline A. hydrophila & 6 & $3(1)$ & & $3(1)$ & $0.70(0.01)$ & $3(3)$ & $1.43(0 \cdot 18)$ \\
\hline A. sobria & 11 & $3(1)$ & & $3(1)$ & $0.50(0.03)$ & $8(5)$ & $0.80(0.20)$ \\
\hline A. caviae & 20 & $7(1)$ & & $7(1)$ & $0.45(0.02)$ & $13(9)$ & $0.66(0.10)$ \\
\hline Positive control* & & & & & $1 \cdot 20(0 \cdot 20)$ & & \\
\hline Negative control $\dagger$ & & & & & $0.00(0.00)$ & & \\
\hline Total & 66 & $22(6)$ & $2(1)$ & $24(7)$ & & $42(31)$ & \\
\hline
\end{tabular}

Figures in parenthesis indicate number of enterotoxigenic strains in the initial tests before passage in RILs.

* BHIB culture of $V$. cholerae strain 569B.

+ BHIB.

Table III. Serum-sensitivity of 18 representative strains of Aeromonas incubated in NHS and in NHS with MgEGTA

\begin{tabular}{|c|c|c|c|c|c|c|c|}
\hline \multirow{3}{*}{$\begin{array}{l}\text { Species of } \\
\text { isolate }\end{array}$} & \multirow{3}{*}{$\begin{array}{c}\text { Strain } \\
\text { no. }\end{array}$} & \multicolumn{6}{|c|}{ Percentage survival of inoculum* after incubation with } \\
\hline & & \multicolumn{3}{|c|}{ NHS + PBS for } & \multicolumn{3}{|c|}{ NHS + MgEGTA for } \\
\hline & & $30 \mathrm{~min}$ & $60 \mathrm{~min}$ & $120 \mathrm{~min}$ & $30 \mathrm{~min}$ & $60 \mathrm{~min}$ & $120 \mathrm{~min}$ \\
\hline \multicolumn{8}{|c|}{ Serum sensitive (prompt) } \\
\hline \multirow[t]{2}{*}{ A. hydrophila } & C-96011 & 38 & $<1.0$ & $<0.01$ & 103 & 162 & $<1 \cdot 0$ \\
\hline & E-6 & $<1$ & $<0 \cdot 1$ & $<0.01$ & 36 & 18 & $<0 \cdot 1$ \\
\hline \multirow{2}{*}{ A. sobria } & $\mathrm{C}-21$ & $<1$ & $<0 \cdot 1$ & $<0.01$ & 93 & 80 & $8 \cdot 0$ \\
\hline & E-PDG1 & $<1$ & $<0 \cdot 1$ & $<0.01$ & 163 & 158 & $<0.1$ \\
\hline \multirow[t]{5}{*}{ A. caviae } & $\mathrm{C}-62$ & 114 & $<0 \cdot 1$ & $<0.01$ & 274 & 941 & $<0 \cdot 1$ \\
\hline & $\mathrm{C}-12$ & 29 & $4 \cdot 0$ & $<1.0$ & 34 & 3 & $<0 \cdot 1$ \\
\hline & C- 230 & 57 & $7 \cdot 0$ & $<1.0$ & 33 & 6 & $<1.0$ \\
\hline & E-31 & $<1$ & $<0 \cdot 1$ & $<0.01$ & 227 & 43 & $<0.1$ \\
\hline & E-29 & $<1$ & $<0 \cdot 1$ & $<0.01$ & 198 & 52 & $<0.1$ \\
\hline \multicolumn{8}{|c|}{ Serum sensitive (delayed) } \\
\hline \multirow[t]{2}{*}{ A. sobria } & C-5 & 123 & 85 & $9 \cdot 0$ & 233 & 133 & $5 \cdot 0$ \\
\hline & C- 10 & 200 & 98 & $5 \cdot 0$ & 152 & 87 & $6 \cdot 0$ \\
\hline \multicolumn{8}{|l|}{ Serum-resistant } \\
\hline \multirow[t]{3}{*}{ A. hydrophila } & C-40 & 115 & 230 & 565 & 205 & 321 & 281 \\
\hline & E-HG1 & 100 & 169 & 18 & 100 & 428 & 564 \\
\hline & E-BD1 & 116 & 177 & 352 & 134 & 206 & 367 \\
\hline \multirow[t]{2}{*}{ A. sobria } & $\mathrm{C}-24$ & 133 & 178 & 400 & 793 & 547 & 433 \\
\hline & E-3 & 213 & 240 & 141 & 120 & 201 & 568 \\
\hline \multirow[t]{2}{*}{ A. caviae } & C-421 & 170 & 229 & 374 & 72 & 147 & 390 \\
\hline & E-SG4T & 253 & 540 & 1330 & 165 & 176 & 243 \\
\hline
\end{tabular}

$\mathrm{C}$, clinical; $\mathrm{E}$, environmental.

* Mean of three determinations with cultures grown on different days and incubated with the same batch of NHS.

more fluid accumulation $(\mathrm{p}<0 \cdot 05$, Student's $t$ test) than those showing NHA (table I). The majority of the strains showing NHA or MGS-HA were non-toxigenic irrespective of species or source, but became toxigenic without change in HA properties after successive passage through RILs (table I).

The majority $(64 \%)$ of the isolates $(55 \%$ of $A$. hydrophila, $62 \%$ of A. sobria and $68 \%$ of A. caviae) were resistant to the bactericidal action of NHS. Most $(92 \%)$ of the serum-sensitive strains were killed promptly, but two of the clinical strains ( $A$. sobria) showed delayed sensitivity (table II). There was no significant correlation between serum sensitivity and species or source of the isolates. Most of the strains that showed prompt sensitivity in NHS (significant decrease in viable counts within $60 \mathrm{~min}$ ) showed only delayed sensitivity (within $120 \mathrm{~min}$ ) in NHS with MgEGTA. The two strains with delayed sensitivity in NHS also showed delayed sensitivity in NHS with MgEGTA (table III).

Accumulation of fluid in RILs was caused by the majority $(74 \%)$ of the serum-resistant isolates when 
tested initially, but by only a minority ( $29 \%$ ) of serumsensitive isolates (table II). These enterotoxigenic serum-resistant strains comprised $100 \%$ of the $A$. hydrophila, $77 \%$ of the A. sobria and $65 \%$ of the $A$. cariae isolates, and they caused significantly more accumulation of fluid ( $\mathrm{p}<0.05$. Student's $t$ test) than the serum-sensitive strains (table II).

\section{Discussion}

In the present study. less than half of the isolates caused HA. Burke et al. ${ }^{9}$ reported that the majority of diarrhoeal isolates of $A$. hidrophila showed HA patterns other than MFS-HA. and that those of $A$. catiae. mostly from non-diarrhoeal or water sources, showed either NHA or MFS-HA. However. our study of three species of Aeromonas showed various $\mathrm{HA}$ patterns including MFS-HA. independent of the source: it suggests that HA patterns may not be correlated with either species or source. although a higher proportion of $A$. hydrophila strains may cause $\mathrm{HA}$.

Haemagglutinating strains of the three species. showing HA patterns including that of MFS-HA, caused fluid accumulation in RILs. Most of the strains showing NHA or MGS-HA were non-toxigenic, apart from some environmental isolates of $A$. caliae, so that there was moderate correlation of HA with enterotoxigenicity. Burke et al. ${ }^{9}$ made similar observations, the only exception being that strains showing MFS$\mathrm{HA}$ in their study were non-toxigenic, whereas almost all such strains in our study produced enterotoxin. The present data are at variance with those of Crichton and Walker. ${ }^{16}$ who found that all strains of Aeromonas spp., whether toxigenic or non-toxigenic, caused HA.

On successive passage through RILs, all of our nontoxigenic strains became enterotoxin producers, suggesting a repression-derepression phenomenon influencing the toxin gene. However, none of the nonhaemagglutinating strains caused HA, even after RIL passage, although they became enterotoxigenic; this suggests that repression-derepression may not apply to the haemagglutinin gene. It seems that there is partial correlation between $\mathrm{HA}$ and enterotoxigenicity of Aeromonas spp. but they are probably not genetically linked.

In intestinal and extra-intestinal infections, $A$.hydrophila and $A$. sobria have been reported to be more virulent and serum-resistant than $A$. catiae ${ }^{1.2,17.18}$ but A. cariae strains have been increasingly implicated in intestinal ${ }^{2.15}$ and extra-intestinal infections including septicaemia and bacteraemia. ${ }^{19}$ Most $A$. caviae isolates (clinical and environmental) in our study were serumresistant, suggesting their potential virulence in these diseases. Furthermore, most of our Aeromonas strains were serum-resistant, regardless of species; and this suggests similar pathogenic potential.

Most of our environmental isolates were resistant to NHS (table II); this may explain the recent reports that extra-intestinal infections by Aeromonas spp. are almost always water-related. ${ }^{1,2,20}$ Our data also suggest that serum resistance is shown almost equally by clinical and environmental isolates, regardless of species. These observations may indicate versatility in the role of Aeromonas spp. in various diseases.

Of the Aeromonas strains studied, $36 \%$ were serumsensitive. Gram-negative bacteria are killed by functional components of both the classical and alternate pathways, by damaging the bacterial cell membrane activity. ${ }^{21}$ EGTA and MgEGTA have recently been used to distinguish these two complement pathways. Serum chelated with EGTA causes disintegration of the $\mathrm{C}_{1}$ complex and blocks the consumption of $\mathrm{C}_{2}$; this prevents activation of the classical pathway and permits activation of the alternate (properdin) pathway, but at an apparently suboptimal concentration of $\mathrm{Mg}^{2+}$. This could be achieved by addition of $\mathrm{MgCl}_{2}$ in equimolar quantity to a solution of EGTA to form MgEGTA, restoring the $\mathrm{Mg}^{2+}$ concentration while moderately reducing the efficiency of $\mathrm{Ca}^{2+}$ chelation. Our results corroborate the earlier observation that strains of Aeromonas spp. with prompt serum-sensitivity were killed by activation of both pathways. ${ }^{17}$ They also indicate that a few strains with delayed sensitivity were killed by activation of the alternate pathway, as was observed with Serratia marcescens. ${ }^{22}$ Thus, Aeromonas strains interact with complement in diverse ways, and this may reflect strain-specific rather than species-related pathogenic potential.

The observation that most serum-resistant strains were enterotoxigenic suggests a possible relationship between these two properties; and the higher enterotoxigenic potential of haemagglutinating and serumresistant strains suggests that these two properties may enhance the virulence of these organisms. However, no correlation was observed between HA or serum sensitivity and species or source of the organism.

The study was supported by a fellowship to D.V.S. from the Council of Scientific and Industrial Research, New Delhi. The authors thank Dr D. C. S. Reddy, Department of Preventive and Social Medicine, for analysing the statistical data and Mr D. Venu Gopal for secretarial assistance.

\section{References}

1. Landa JM. Duffey PS. Mesophilic aeromonads in human
disease: current taxonomy. laboratory identification and
infectious disease spectrum. Rer Infect Dis 1988: 10:
98099 .

3. Annapurna E, Sanyal SC. Enterotoxicity of Aeromonas hydrophila. I Med Microbiol 1977; 10: 317-323.

4. Burke V, Robinson J, Atkinson HM, Gracey M. Biochemical characteristics of enterotoxigenic Aeromonas spp. $J$ Clin Microbiol 1982; 15: 48-52.

5. Barer MR, Millership SE, Tabaqchali S. Relationship of toxin production to species in the genus Aeromonas. I Med Crit Ret Microbiol 1989: 16: 253-286. 
6. Kuijper EJ, Steigerwalt AG, Shoenmakers BSCIM, Peeters $\mathrm{MF}$, Zanen HC, Brenner DJ. Phenotypic characterization and DNA relatedness in human fecal isolates of Aeromonas spp. J Clin Microbiol 1989; 27 : 132-138.

7. Janda JM, Brenden R, Bottone EJ. Differential susceptibility to human serum by Aeromonas spp. Curr Microbiol 1984; 11 : 325-328.

8. Rolston KVI. Human extraintestinal infections caused by Aeromonas species. J Diarrh Dis Res 1988; 2: 99-102.

9. Burke V, Cooper M, Robinson J et al. Haemagglutination patterns of Aeromonas spp. in relation to biotype and source. J Clin Microbiol 1984; 19: 39-43.

10. Popoff M. Genus III. Aeromonas. Kluyver and Van Niel. 1936 In: Kreig NR, Holt JG (eds) Bergey's manual of systematic bacteriology, 9th edn, vol 1. Baltimore, Williams and Wilkins Co. 1984: 545-548.

11. Atkinson HM, Trust TJ. Haemagglutination properties and adherence ability of Aeromonas hydrophila. Infect Immun 1980; $27:$ : 938-946.

12. Fine DP, Morney SR, Colley DG et al. $\mathrm{C}_{3}$ shunt activation in human serum chelated with EGTA. J Immunol 1972; 109: 807-809.

13. Carruthers MM, Kabat WJ. Vibrio vulnificus (lactose-positive vibrio) and Vibrio parahaemolyticus differ in their susceptibilities to human serum. Infect Immun 1981; 32: 964-966.

14. De SN, Chatterje DN. Experimental study of the mechanism of action of Vibrio cholerae on the intestinal mucous membrane. J Pathol Bacteriol 1953; 66: 559-562.

15. Singh DV, Sanyal SC. Enterotoxicity of clinical and environmental isolates of Aeromonas spp. J Med Microbiol 1992; 36: $269-272$.

16. Crichton PB, Walker JW. Methods for the detection of haemagglutinins in Aeromonas. J Med Microbiol 1985; 19 : 273-277.

17. Brenden R, Janda JM. The interaction of complement components with Aeromonas species. Can J Microbiol 1986; 32: 1-3.

18. Palumbo SA, Bencivengo MM, Corral FD et al. Characterization of the Aeromonas hydrophila group isolated from retail foods of animal origin. $J$ Clin Microbiol 1989; 27 : 854-859.

19. Janda JM, Brenden R. Importance of Aeromonas sobria in Aeromonas bacteremia. J Infect Dis 1987 ; 155: 589-591.

20. Joseph SW, Daily OP, Hunt WS, Seidler RJ, Allen DA, Colwell RR. Aeromonas primary wound infection of a diver in polluted waters. J Clin Microbiol 1979; 10: 46-49.

21. Taylor PW. Bactericidal and bacteriolytic activity of serum against gram-negative bacteria. Microbiol Rev 1983; 47: 46-83.

22. Traub WH, Kleber I. Selective activation of classical and alternative pathways of human complement by "promptly serum-sensitive" and "delayed serum-sensitive" strains of Serratia marcescens. Infect Immun 1976; 13: 1343-1346. 